\title{
FREQUENCY OF 2,3,5-TRIPHENYLTETRAZOLIUM CHLORIDE (TTC) NON-REDUCING BACTERIA IN PASTEURIZED MILK
}

\author{
Vanerli Beloti'1,2; Márcia A.F. Barros²; Júlio C. de Freitas²; Luís A. Nero²; Juliana A. de Souza²; \\ Elsa H.W. Santana ${ }^{2}$; Bernadette. D.G.M. Franco ${ }^{{ }^{*}}$.
}

${ }^{1}$ Departamento de Alimentos e Nutrição Experimental, Faculdade de Ciências Farmacêuticas, Universidade de São Paulo-USP, São Paulo, SP, Brasil. ${ }^{2}$ Laboratório de Inspeção de Produtos de Origem Animal, Departamento de Medicina Veterinária Preventiva, CCA, Universidade Estadual de Londrina, Londrina, PR, Brasil.

Submitted: March 22, 1999; Returned to authors for corrections: May 21, 1999; Approved: June 23, 1999

\begin{abstract}
2,3,5-triphenyltetrazolium chloride (TTC) is a dye largely used for enumeration of microbial colonies in solid culture media, being a key component of the dry rehydratable film system used for microbiological analysis of food. This dye is colorless in the oxidized form and red when reduced by microorganisms, due to formation of formazan. In this study, TTC was added to Plate Count Agar (PCA) for enumeration of microorganisms in thirty four pasteurized milk samples, with the aim to verify the frequency of microorganisms that are unable to reduce TTC. Milk samples were decimally diluted in saline and pour-plated in PCA plus $0.015 \%$ TTC. Colonies were counted after $24 \mathrm{~h}$ and $48 \mathrm{~h}$ of incubation at $35^{\circ} \mathrm{C}$. From a total of 50,574 colonies, 19,665 (38.88\%) did not reduce TTC in $48 \mathrm{~h}$. It was observed that 571 (6.36\%) colonies that were colorless in $24 \mathrm{~h}$ became red in $48 \mathrm{~h}$. From those that didn't reduce TTC in 48h, 233 were purified and Gram stained. 229 (98.71\%) of them were Gram positive cocci and bacilli. The results show that there is a high percentage of microorganisms unable to reduce TTC in pasteurized milk, which cannot be detected by laboratory procedures based on the formation of red colonies.
\end{abstract}

Key words: 2,3,5-triphenyltetrazolium chloride, TTC, pasteurized milk, microbial counts

\section{INTRODUCTION}

2,3,5-triphenyltetrazolium chloride (TTC) is a dye largely used for enumeration of microbial colonies in solid culture media (21). This dye is a key component of the dry rehydratable film system used for microbiological analysis of food $(5,6,20)$. TTC is colorless in the oxidized form and red when reduced.
Live microorganisms reduce TTC by enzymatic action (10), originating formazan which is kept inside granules in the cells, which become red (15).

TTC was synthesized by Pechmann and Runge in 1894 (18). In 1941, Kuhn and Jerchel (11) demonstrated that bacteria, yeasts and plants are able to reduce this dye. One of the first applications of TTC was to verify the germination capacity of seeds (2). Since then, many

\footnotetext{
* Corresponding author. Mailing address: Universidade de São Paulo, Faculdade de Ciências Farmacêuticas, Departamento de Alimentos e Nutrição Experimental, Av. Prof. Lineu Prestes 580, CEP 05508-900, São Paulo, SP, Brasil. Fax: (+5511) 815-4410, E-mail: bfranco@usp.br
} 
other applications were reported, including the use of TTC in microbiology $(4,10,12,17,23)$. Huddleson and Baltzer (7) observed that colonies of different microbial species or varieties of the same specie may develop several shades of red when plated in medium with TTC. Gershenfeld and Weber Jr. (3) reported that coagulase-positive Staphylococcus sp. form colonies with an orange center when TTC is added to the medium, while coagulase negative Staphylococcus $\mathrm{sp}$. colonies are pink. Turner et al. (22) observed that Streptococcus cremoris could be differenciated from Streptococcus lactis with the use of TTC, because it is able to reduce the dye while the other is not. Similarly, Rioux et al. (19) reported that C. albicans could be distinguished from other yeasts, because they form pink colonies in medium with TTC, while other yeast colonies are white.

Some factors, like $\mathrm{pH}$, temperature, light and concentration of the dye, also interfere in TTC reduction. The reduction of TTC is more intense at high $\mathrm{pH}(9)$. The concentration of TTC added to the culture medium is very important because high levels may have a deleterious effect (21). Consequently, the concentration of TTC used in culture media should be low enough to avoid inhibition of growth, but high enough to allow color development $(8,15)$.

The variation in the capacity to reduce TTC by many microorganisms may be beneficial for their differentiation, but, in techniques where TTC is used to help the counting of colonies, this variation may be pose a problem. The colonies of microorganisms that are unable to reduce TTC are not red, and consequently, may not be counted, leading to errors.

The dry rehydratable film system for microbiological analysis of food is largerly used in many countries, including Brazil. It has several advantages, like simplicity and accuracy and is costeffective $(5,6,20)$. However, the application of this system for counts of aerobic bacteria in Brazilian pasteurized milk has been hampered by counts that are frequently lower than those obtained by the conventional plating procedure (21) in this particular type of food (Franco, B.D.G.M. personnal communication). This phenomenon seems to be restricted to pasteurized milk produced in certain regions of Brazil. The objective of this study was to survey the frequency of microorganisms that are unable to reduce TTC in pasteurized milk produced in one of these regions, and to determine how these microorganisms would interfere in the accuracy of the dry rehydratable film system.

\section{MATERIALS AND METHODS}

\section{Determination of minimal inhibitory} concentration of TTC in pasteurized milk: Five pasteurized milk samples, purchased from local stores in the city of Londrina, Paraná, BR, were submitted to decimal dilutions in $0.85 \%$ saline $\left(10^{-1}\right.$, $10^{-2}$ and $10^{-3}$ ), according to Lanara (1) and $1 \mathrm{ml}$ of each dilution of each sample was pour-plated, in duplicates, in Plate Count Agar - PCA (Difco) containing $0.005 \%, 0.01 \%, 0.015 \%, 0.025 \%$ or $0.05 \%$ TTC (Sigma) and also in PCA without TTC. Plates were incubated at $35^{\circ} \mathrm{C}+/-1^{\circ} \mathrm{C}$ for 24 hours and 48 hours, and the number of $\mathrm{CFU} / \mathrm{ml}$ of pasteurized milk was determined according to the counting procedures recommended by Swanson et al. (21). All colonies were counted, regardless their color or size.

Frequency of TTC non-reducing microorganisms in pasteurized milk: 34 samples of pasteurized milk, produced by dairies in the region of the city of Londrina, Paraná, BR, were purchased from local stores, and transported under refrigeration to the Laboratory of Inspection of Animal Products, Department of Preventive Veterinary Medicine, Londrina State University. All samples were submitted to decimal dilutions in $0.85 \%$ saline, and $1 \mathrm{ml}$ of each dilution was pour-plated, in duplicates, in PCA containing $0.015 \%$ TTC and also in PCA without TTC. The desired concentration of TTC in PCA was achieved using a $0.5 \%$ "mother-solution", kept in amber flasks covered with aluminum foil and maintained under refrigeration until the moment of use. PCA plates were incubated at $35^{\circ} \mathrm{C}$. Colony Forming Units (CFUs) were counted after 24 hours and 48 hours of incubation, The number of CFU/ $\mathrm{ml}$ in each sample was determined according to Swanson et al. (21). Colonies were classified according to color: colorless, white, cream or yellow were considered TTC non-reducers and pink or red were considered TTC reducers. Colonies that changed color between the two countings were also recorded.

Preliminary identification of TTC non-reducing colonies: After 48 hours of incubation, hundreds of colonies considered as non reducers were streaked on PCA with $0.015 \%$ TTC and on Blood Agar. Plating was repeated until pure cultures were obtained. From these, 233 were selected for Gram staining. 


\section{RESULTS AND DISCUSSION}

Besides facilitating the counting of colonies, TTC is also a powerful tool to distinguish colonies from food particles, which don't react with the dye. Use of TTC is highly recommended for milk testing, because the opacity of the plates, specially those containing the less diluted samples, makes the counting unaccurate (16). Many microbiologists use TTC added to the media as an over-lay after incubation rather than added to PCA prior to plating, because TTC may be deleterious to many microorganisms (4). In this study, TTC was used as a supplement of PCA because further testing of colonies grown on the agar was needed. Futhermore, in the dry rehydratable film procedure, TTC is also part of the film $(5,6,20)$.

The best performance of TTC for counting of colonies in PCA was achieved by the concentration of $0.015 \%$ and very little inhibition of microbial growth was observed when compared to counts in PCA with no dye. TTC reducing colonies were easily distinguished from those that didn't reduce the dye. There isn't a consensus on the ideal concentration of TTC for colony counting. According to Swanson et al. (21), the concentration of TTC in the agar should be $0.005 \%$. May et al. (13) reported that $0.05 \%$ TTC was not inhibitory for Gram negative bacteria, including E.coli. For Gram positives, like B.subtilis and S.pyogenes, the minimal inhibitory concentration (MIC) was $0.0032 \%$. Ohara (16) observed that $0.1 \%$ and $2 \%$ TTC should be used for bacteria and yeasts countings, respectively.

From a total of 50,574 colonies counted in PCA with $0.015 \%$ TTC, 19,665 (38.88\%) were not able to reduce the dye in 48 hours. After incubation of 24 hours, among 28,717 colonies, 8,983 (31.28\%) did not reduce TTC. From the 21,857 colonies that grew in the second incubation of 24 hours, 10,682 $(48.87 \%)$ were non-reducers (Table 1$)$. Between the two countings, $571(6.36 \%)$ non-reducer colonies changed to pink.

Table 1. Frequency of TTC reducing and non-reducing microorganisms in pasteurized milk, determined by pour-plating in Plate Count Agar supplemented with $0.015 \%$ TTC, incubated at $35^{\circ} \mathrm{C}$ during $24 \mathrm{~h}$ and $48 \mathrm{~h}$.

\begin{tabular}{cccccc}
\hline & \multicolumn{2}{c}{ TTC reducing } & & \multicolumn{2}{c}{ TTC non-reducing } \\
\cline { 2 - 3 } \cline { 5 - 6 } \cline { 5 - 6 } & $\mathrm{n}^{\mathrm{o}}$ & $\%$ & & $\mathrm{n}^{\mathrm{o}}$ & $\%$ \\
\hline 24h counting & 19,734 & 68.72 & & 8,983 & 31.28 \\
48h counting & 30,909 & 61.12 & & 19,665 & 38.88 \\
\hline
\end{tabular}

Comparing the number of colonies obtained in PCA with and without TTC, after 48 hours, a $6.16 \%$ inhibition was detected. The number of colonies in PCA was 53.896 CFUs, while in PCA with $0.015 \%$, the number was 50.574 CFUs. The size of the colonies in the medium with TTC was a little smaller when compared to the same sample plated in PCA without TTC. Among the colonies submitted to Gram stain, $110(47.21 \%)$ were Gram positive coccobacilli, 80 (34.33\%) were Gram positive bacilli, $33(14.16 \%)$ were Gram positive cocci, 4 (1.72\%) were yeasts, 3 (1.29\%) were Gram negative bacilli, $2(0.86 \%)$ were actinomyces and $1(0.43 \%)$ was a Gram negative coccobacillus. These data show that more than $95 \%$ of the TTC non-reducer colonies were Gram positive bacteria and only less than $2 \%$ were Gram negative (Table 2).

Table 2. Characteristics of TTC non-reducing microorganisms isolated from pasteurized milk.

\begin{tabular}{lcc}
\hline colonies & Number & Percentage \\
\hline Gram positive coccobacilli & 110 & $47.21 \%$ \\
Gram positive bacilli & 80 & $34.33 \%$ \\
Gram positive cocci & 33 & $14.16 \%$ \\
Yeasts & 4 & $1.72 \%$ \\
Gram negative bacilli & 3 & $1.29 \%$ \\
Actinomyces & 2 & $0.86 \%$ \\
Gram negative coccobacilli & 1 & $0.43 \%$ \\
\hline Total & 233 & $100 \%$ \\
\hline
\end{tabular}

Gram positive microorganisms, like Micrococcus, coryneforms and some heat resistant bacilli are often present in raw milk and are part of remaining microflora in pasteurized milk. In counterpart, Gram negative microorganisms are much less common in raw milk. This suggests that the TTC non-reducing Gram positive bacteria detected in the pasteurized milk samples are those that survived to the heat treatment. Their incapacity to reduce TTC before the pasteurization was done could not not tested, but sucessive platings of many of these colonies in non-selective Blood Agar plates didn't make them them able to reduce TTC. This suggests that a possible heat-injury that affected the capacity of microorganisms to reduce TTC was irreversible.

\section{RESUMO}

\section{Freqüência de bactérias não-redutoras de cloreto de 2,3,5-trifeniltetrazólio (TTC) em leite pasteurizado}


Cloreto de 2,3,5-trifeniltetrazólio (TTC) é um corante muito utilizado para contagem de colônias de microrganismos em meios de cultura sólidos, sendo um componente-chave do sistema de filme seco rehidratável usado para a análise microbiológica de alimentos. Esse corante é incolor na forma oxidada e vermelho quando reduzido por microrganismos, devido a formação de formazano. Nesse trabalho, TTC foi adicionado a Agar Padrão para Contagem (PCA) para enumeração de microrganismos em trinta e quatro amostras de leite pasteurizado, com o objetivo de se determinar a freqüência de microrganismos incapazes de reduzir o TTC. As amostras de leite foram submetidas a diluições decimais e a plaqueamento em profundidade em PCA com $0,015 \%$ de TTC. As colônias foram enumeradas após $24 \mathrm{~h}$ e $48 \mathrm{~h}$ de incubação a $35^{\circ} \mathrm{C}$. De um total de 50.574 colônias, 19.665 (38,88\%) não reduziram TTC em 48h. Observou-se que $571(6,36 \%)$ colônias incolores em 24 ficaram vermelhas em $48 \mathrm{~h}$. Entre as colônias não redutoras de TTC, 233 foram purificadas e submetidas à coloração Gram, verificando-se que $229(98,71 \%)$ eram cocos ou bacilos Gram positivos. Os resultados indicam que há uma elevada porcentagem de bactérias não redutoras do TTC em leite pasteurizado, e, portanto, não são detectadas quando são utilizados métodos laboratoriais baseados na formação de colônias vermelhas.

Palavras-chave: cloreto de 2,3,5-trifeniltetrazólio, TTC, leite pasteurizado, contagem de microrganismos

\section{REFERENCES}

1. Brasil. Ministério da Agricultura - Secretaria Nacional de Defesa Agropecuária, Laboratório Nacional de Referência Animal - LANARA. Métodos analíticos oficiais para controle de produtos de origem animal e seus ingredientes. Volume II - Métodos Físicos e Químicos, 1981.

2. Brewer, H. E. Tetrazolium chloride as a test for damage in artificially cured peanuts. Science, 110 (2861): 451-452, 1949

3. Gershenfeld, L.,: Weber, Jr L.S. Bacterial variants produced in culture media containing 2,3,5-triphenyltetrazolium chloride. Am. J. Pharm., 123 (6): 203-207, 1951

4. Gunz, F. W. Reduction of tetrazolium salts by some biological agents. Nature, London, 163 (4133): 98, 1949

5. Ginn, R.E.; Packard, V.S.; Fox, T.L. Enumeration of total bacteria and coliforms in milk by dry rehydratable film method: collaborative study. J. Assoc. Off. Anal. Chem., 69:527-571, 1986
6. Ginn, R.E.; Packard, V.S.; Fox, T.L. Evaluation of the 3M dry medium culture plate (Petrifilm ${ }^{\mathrm{TM}} \mathrm{SM}$ ) method for determining numbers of bacteria in raw milk. J.Food Prot. 47:753-755, 1984

7. Huddlesson, F.; Baltzer, B. Differentiation of bacterial species and variation within species by means of $2,3,5-$ triphenyltetrazolium chloride in culture medium. Science 112 (2918):651-652, 1950

8. Hurwitz, C. N.; Mc Carthy, T. J. 2,3,5-triphenyltetrazolium chloride as a novel tool in germicide dynamics. J. Pharm. Sci., 75 (9): 912-916, 1986

9. Jones, P. H.; Prasad, D. The use of tetrazolium salts as a measure of sludge activity. J. Water Poll. Control Fed. 41 (11): R441-R449, 1969

10. Kenner, B. A.; Clark, H. F.; Kabler, P. W. Fecal streptococci. I. Cultivation and enumeration of streptococci in surface waters. Appl. Microbiol, 9: 15-20, 1961

11. Kuhn, R.; Jerchel, D. Ber. Deutsch. Chem. Ges., 74-B: 949, 1941. Apud: Gunz, F. W. Reduction of tetrazolium salts by some biological agents. Nature, London, 163, (4133); 98, 1949

12. Matalon, M. E.; Sandine, W. E. Improved media for differentiation of rods and cocci in yogurt. J. Dairy Sci., 69 (10): 2569-2576, 1986

13. May, P. S.; Winter, J. W.,; Fried, G. H.; Antopol, W. Effect of tetrazolium salts on selected bacterial species. Proc. Soc. Exp. Biol. Med., 105 (2): 364-365, 1960

14. Mudd, S.; Winterscheid, L.C.; Delamater, E. D.; Henderson, $\mathrm{H}$. J. Evidence suggesting that the granules of mycobacteria are mitochondria. J. Bacteriol., 62 (4): 459-475, 1951

15. Mustakallio, K. K.; Ahos, E. O. Tetrazolium reduction test for milk. Science, 122: 971-972, 1955

16. Ohara, M.T. Aplicação do cloreto de trifeniltetrazólio no teste de limite microbiano em medicamentos e cosméticos. São Paulo, 1992, 212p. (Ph.D. Thesis. Faculdade de Ciências Farmacêuticas. USP.)

17. Pagano, J.; Levin, J. D.; Trejo, W. Antibiotics Annual, 19571958, 137-143. Apud: Rioux, J. A., Bastide, J. M., Galzy, P. La réducion des sels de tétrazolium par les levrures; application a la détermination rapide de quelques especes du genne Candida. Trav. Pharm. Montpellier, 20 (1): 41-46, 1960

18. Pechmann, H. V.; Runge, P. Ber. Deutsch. Chem. Ges., 27: 2920, 1894. Apud: Gunz, F. W. Reduction of tetrazolium salts by some biological agents. Nature, London, 163, (4133); 98, 1949

19. Rioux, J. A.; Bastide, J. M.; Galzy, P. La réducion des sels de tétrazolium par les levrures; applicacion a la détermination rapide de quelques especes du genne Candida. Trav. Pharm. Montpellier, 20 (1): 41-46, 1960

20. Swanson, K.M.J.; Busta, F.F.; Peterson, E.H.; Johnson, M.G. Colony count methods. In: Vanderzant, C., Splittstoesser, D.F. (eds) Compendium of methods for the microbiological examination of foods. APHA, Washington, 1992, p. 75-95

21. Senyk, G.F.; Kozlowski, S.M.; Noar, P.S.; Shipe, W.F.; Bandler, D.K. Comparison of dry culture medium and conventional plating techniques for enumertaion of bacteria in pasteurized fluid milk. J. Dairy Sci., 70:1152-1158, 1987

22. Turner, N.; Sandine, W. E.; Elliker, P. R.; Day, E. A. Use of tetrazolium dyes in an agar medium for differentiation of Streptococcus lactis and Streptococcus cremoris. J. Dairy Sci., 46: 380-385, 1963

23. Wood, R. M. Brucella ring test antigen prepared by reduction of tetrazolium salt. Science, 112(2899):86, 1950 